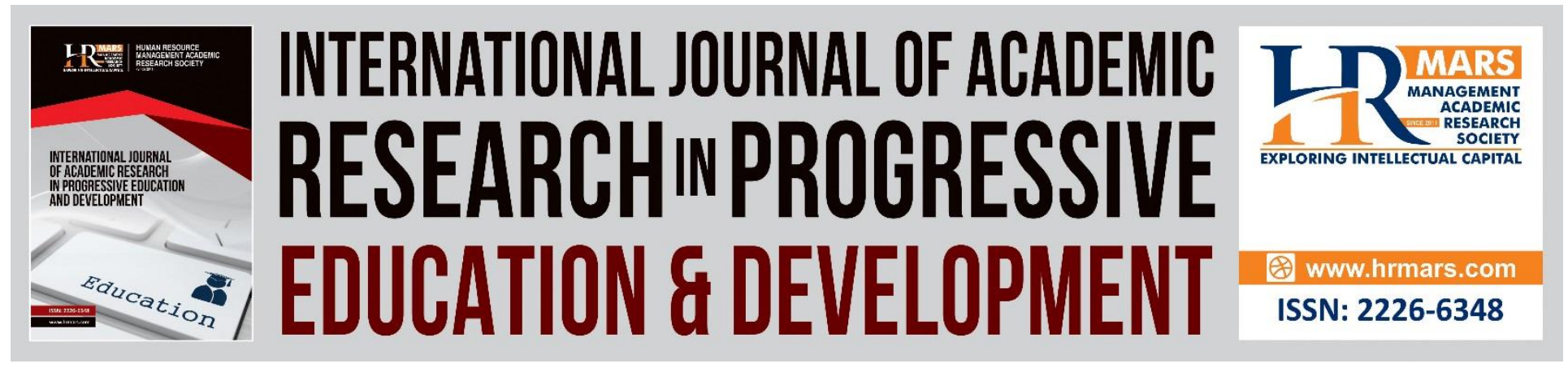

\title{
Human Capital for Sustainable Development: A Conceptual Framework for Institutes of Higher Education
}

\author{
Hamoon Khelghat-Doost, Suzyrman Sibly
}

To Link this Article: http://dx.doi.org/10.6007/IJARPED/v9-i2/7220

DOI:10.6007/IJARPED/v9-i2/7220

Received: 20 January 2020, Revised: 24 February 2020, Accepted: 19 March 2020

Published Online: 30 March 2020

In-Text Citation: (Khelghat-Doost \& Sibly, 2020)

To Cite this Article: Khelghat-Doost, H., \& Sibly, S. (2020). Human Capital for Sustainable Development: A Conceptual Framework for Institutes of Higher Education. International Journal of Academic Research in Progressive Education and Development, 9(2), 55-68.

Copyright: (C) 2020 The Author(s)

Published by Human Resource Management Academic Research Society (www.hrmars.com)

This article is published under the Creative Commons Attribution (CC BY 4.0) license. Anyone may reproduce, distribute, translate and create derivative works of this article (for both commercial and non-commercial purposes), subject to full attribution to the original publication and authors. The full terms of this license may be seen

at: http://creativecommons.org/licences/by/4.0/legalcode

\section{Vol. 9(2) 2020, Pg. 55 - 68}

Full Terms \& Conditions of access and use can be found at http://hrmars.com/index.php/pages/detail/publication-ethics 


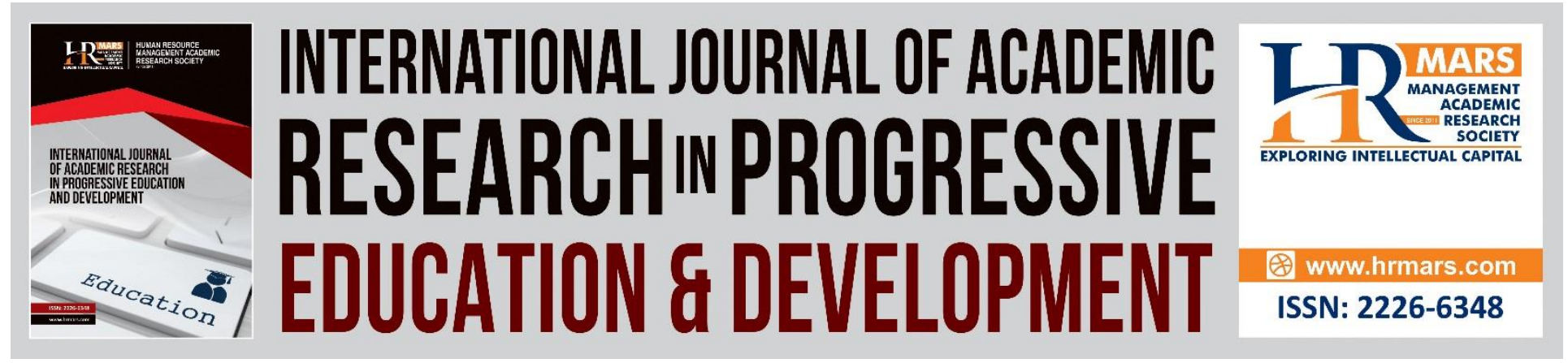

\title{
Human Capital for Sustainable Development: A Conceptual Framework for Institutes of Higher Education
}

\author{
Hamoon Khelghat-Doost, Suzyrman Sibly \\ Centre for Global Sustainability Studies, Universiti Sains Malaysia \\ Email: hamoon@usm.my, suzyrman@usm.my
}

\begin{abstract}
The role of higher education in navigating the development of human capital towards sustainability is vital. It is often argued that higher education should take the lead in training and educating the community and society for the cause of sustainability however, what is usually being ignored is the enhancement of the human capital within the higher education sector itself. In order to create a constructive relation between the higher education sector and the community for developing human capital, the higher education itself should adopt initiatives for developing its own human capital towards sustainability. This paper examines and argues the ways human capital in higher education sector (both administrative and academic staffs) can be trained and developed for sustainability. This approach would also enable the higher education sector to extend its sustainability outreach activities in developing the human capital beyond its borders. This paper therefore examines some of the most important elements in developing the human capital in higher education sector such as; personnel selection, development, motivation, policy, codes and auditing.
\end{abstract}

Keywords: Human Capital, Sustainable Development, Higher Education, leadership.

\section{Introduction}

Universities have been traditionally defined as centers for teaching and research. Through their teaching activities, universities offer specialized training for different sectors of the society, as well as the education essential for the development of the personality (Adomssent et al. 2007; Darwish, 2014). University education boosts the theoretical knowledge of the different divisions of the society as well as offering practical solutions to the societies' dilemmas (Altbach, 1993). The traditional framework of a university is mainly consisted of its close circle of students and lecturers. This isolated compound is usually referred to as the 'ivory tower' (Etzkowitz et al. 2000). Throughout history, it has been always the elites who were privileged to impose their will over the masses of societies through different channels including higher education and 
universities. Traditionally, higher education has been always affiliated to the privileged portions of societies (Guri-Rosenblit, 1996).

However, in shade of the new century and millennium, universities all over the world are beginning to realize that their roles are changing rapidly in a globalizing world. In most countries in the world, accessing higher education is no longer a privilege for a special sector of a society. Because of diversification and massification of higher education, all society members regardless of race, religion, gender and social status can access the services offered by institutes of higher education (Burke, 2013). Nevertheless, the full benefit from a university can be obtained only if the university and society are organically linked together. Raised in another way, the needs of society have to be at the center of a university's activities, and a flexible adjustment to changing needs is necessary.

Recognizing the role which higher education can play in development of more equitable and sustainable societies, the United Nations has launched a decade of education for sustainable development in 2005. As was mentioned in Section 6 of the Bonn Declaration 2009, 'education for sustainable development is setting a new direction for education and learning for all. It promotes quality education, and is inclusive of all people. It is based on values, principles and practices necessary to respond effectively to current and future challenges.'

With large pools of disciplinary experts, high quality research facilities, best infrastructure and a cohort of students with varied academic interests, universities have considerable comparative advantage to promote sustainability in the communities they serve (Čiegis, \& Gineitienè, 2006). Sustainable development being a very complex process, there are no standard recipe for the whole world. Universities, with their core values of search for 'truth' and insight for innovation, have a profound role to play in developing students' capacity to adaptively manage the changing world.

Universities are rarely discussed from the perspective of the 'tragedy of the commons' (Brown, 2000). However under the force of globalization, this is what taking places between universities and the societies (business communities, public communities, etc.). Although universities in their missions have an excellent on serving the needs of both the university itself and the outside community, but they are too often trapped in reconciling the conflicts of interest which at the end making the university the dumping ground, the scapegoat or a testing platform for different problems such as; the environmental, social, economic, etc. Some wiser approaches have been already introduced to change this situation for better. Various kinds of reformations are taking place among different universities which have ended up in few new concepts such as; quality assurance, policy revisions, university corporatization, etc.

This paper therefore briefly develops a conceptual framework for the development of human capital for sustainable development in higher education by discussing three main elements of institutional leadership, campus community, and monitoring and evaluation. The following chart demonstrates the structure of this framework: 


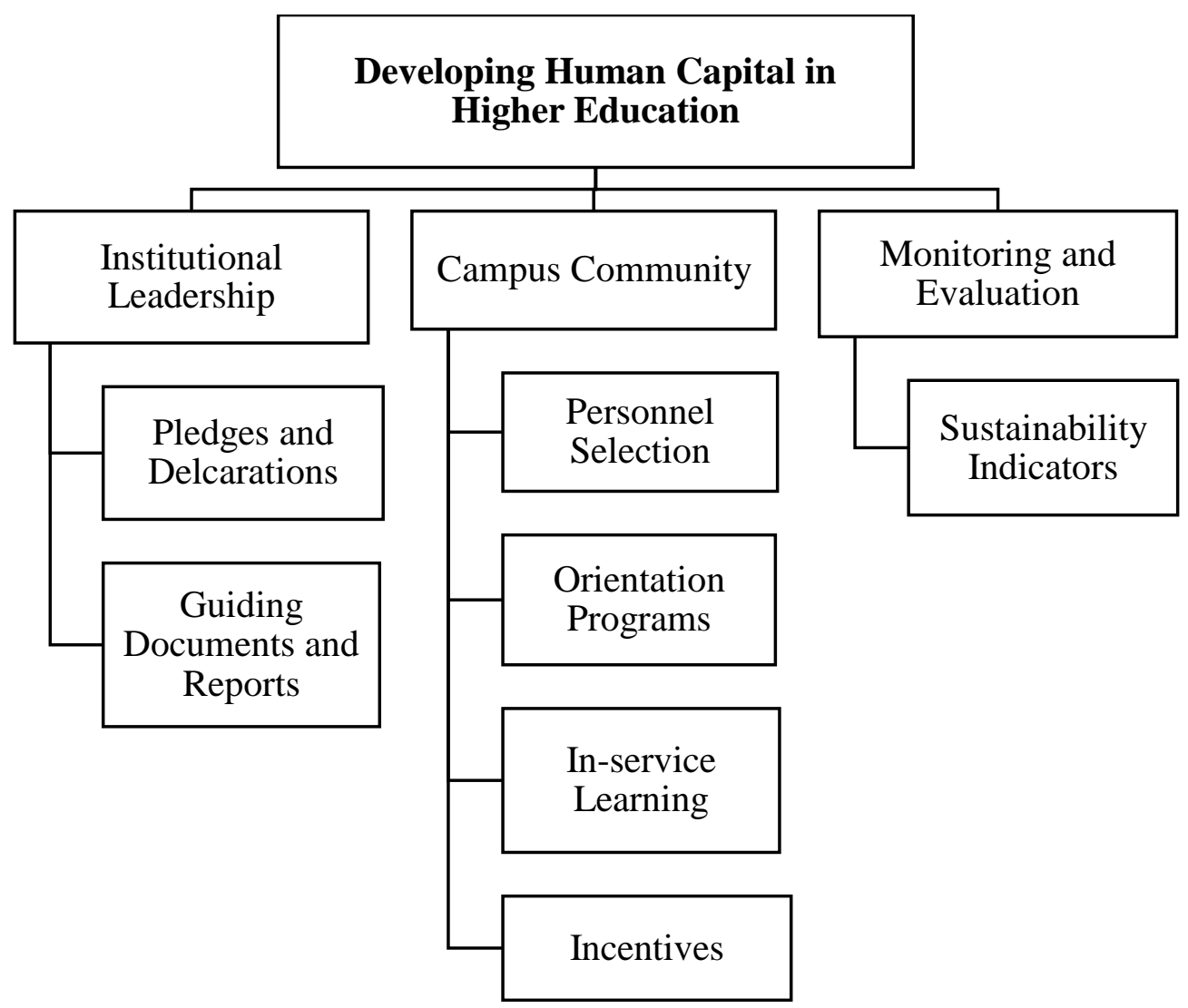

Figure 1: Framework of Developing Human Capital for Sustainable Development in Higher Education

\section{Background}

United Nations declared years 2005-2014 the Decade of Education for Sustainable Development, with the aim of incorporating the main elements, ethics and practices of sustainable development into all levels of education and learning (Borys, 2010). Although the concept has created excitement among universities around the world, however, in reality, the concept of infusing sustainability into higher education still remains a massive challenge for many institutes of higher education. Infusion of sustainability into education system has been emphasized by several other recent global initiatives including Millennium Development Goals (2000) and Sustainable Development Goals (2015) however, the questions such as; what to do, or how to do it; are among the frequently asked questions on this issue.

Most universities around the world still practice a very much disciplined way of research, teaching and administrating. This is the main obstacle against implementing a holistic concept such as sustainability as complex nature of today's challenges demands academicians to step beyond the limits of their own discipline (Tappeiner et al., 2007). These disciplines and clusters obviously are not compatible with the broad nature of sustainability. The challenge of transforming the already established structure of universities cannot be easily overcome. Although many institutes of higher education around the world are making important steps toward necessary changes in education, transforming the traditional higher education system towards a sustainable one is not an easy task (Cortese, 1999). 
Looking at the definition of sustainable development as a development which 'meets the needs of the present without compromising the ability of future generation to meet their own needs' shows it clearly that this concept cannot be limited to a number of disciplines or areas, but it is applicable to the whole world and everyone and everything on it, now and in the future (Frazzoli et al., 2009). In term of the connection between the definition of sustainable development and the concept of education, Agenda 21, the international action plan drawn up at the United Nations Conference on the Environment and Development (UNCED, Rio, 1992) identifies education as having a crucial role to play in this. It clearly states that 'education is critical for promoting sustainable development' and that 'countries should stimulate educational establishments in all sectors, especially the tertiary sector, to contribute more to awareness building' (Sitarz, 1993).

Since sustainable development sounds like a relatively new concept in higher education, it is important to realize that many sustainability related activities and elements already exist in the current curriculum and structure of many universalities around the world (Painter-Morland et al., 2016). Therefore, it is necessary to take note that sustainability in higher education is not a revolution but an evolution of the current existing platform. On the other hand, it is important to realize that in many occasions the current framework of higher education is unable of accommodating sustainability in itself and therefore a fundamental change is needed to make it compatible with sustainability. Sterling (2004) argues that 'sustainability does not simply require an 'add-on' to existing structures and curricula but implies a change of fundamental paradigm in our culture and hence also in our educational thinking and practice. Seen in this light, sustainability is not just another issue to be added to an overcrowded curriculum, but a gateway to a different view of curriculum, of pedagogy, of organizational change, of policy and particularly of ethos'.

Carlson (2006) in an article on sustainable campus in the Chronicle of Higher Education argues that university initiatives on sustainability are only minor steps to gain the appearance of sustainability or 'greenwashing.' Blanco-Portela et al. (2017) points out that universities have been taking a very slow approach compared to corporations in incorporating elements of sustainability into their institutions. It is also argued that universities are supposed to be on the leading edge, but they are falling behind the curve as sustainability has not really been integrated in the higher education seriously (Krizek et al., 2012).

Therefore, considering the way Cortese (2001) defines a sustainable university can help us understanding the fundamental elements of this paper in the upcoming sections better 'a sustainable university can be considered as an institute of higher education as a whole or as a part, that addresses, involves and promotes, on regional or global level, the minimization of environmental, economics, societal and health negative effects in the use of their resources in order to fulfill its main functions in teaching, research, outreach and partnership, and stewardship among others as a way in helping the society make the transition to sustainable lifestyles.'

The main criteria in defining the framework for developing human capital in higher education include: 
DEVELOPMENT

Vol. 9, No. 2, 2020, E-ISSN: 2226-6348 @ 2020 HRMARS

\section{Institutional Leadership}

A subject which plays a vital role in developing human capital for sustainable development in institutes of higher education is creating a suitable sustainable system of leadership and governance for this purpose (Shriberg and MacDonald, 2013). In order to achieve this goal, reviewing the existing structure for sustainable development in international level possess a high degree of importance. On the other hand, it is necessary to consider an appropriate national structure to translate the international sustainability agenda into local level. The first step to accomplish this objective is to link the international and national leadership structures on for sustainable development efficiently and comprehensively. This can be achieved by reviewing the existing pledges and declarations on SD around the globe.

The issue of institutional leadership for sustainable development covers a vast range of elements such as; legislation, enforcement, rules and regulations, economic incentives and education. In order to come up with an inclusive leadership strategy for sustainability in higher education, it is important to consider all the above elements comprehensively.

\section{Pledges and Declarations}

In approaching sustainability related issues, it is important to keep it in mind that sustainable development is not only about planning but more of implementing and practices. Interestingly and in parallel to this matter, what give value to the leadership are the practices which that system of leadership makes (Spillane et al., 2001). Therefore, looking at some of the mainstream and well-known pledges and declarations on institutional leadership can be a great assistance in modeling a sustainable institutional leadership.

One of the examples of such agreements is the PrOSPER.Net. The network for the Promotion of Sustainability in Postgraduate Education and Research (ProSPER.Net) is a network of several leading higher education institutions in Asia and the Pacific that have committed to work together to integrate Sustainable Development (SD) into postgraduate courses and curricula. Member institutions involved have strong education and research programs in sustainable development and related fields. The ProSPER.Net academic and research alliance is an effort of the Education for Sustainable Development ESD) Program at the United Nations UniversityInstitute of Advanced Studies to bring about understanding and delivery of ESD and SD at the postgraduate level.

Establishment of the Regional Centers of Expertise (RCE) on Education for Sustainable Development by the United Nations University (UNU) in 2003 was another international effort to synchronize leadership activities within universities towards achieving sustainability. There are currently 175 of RCEs around the world with the objectives of organizing universities' activities in the local context and facilitating the connection between different actors involved in the process of education for sustainable development (Van Dam-Mieras and Rikers, 2007).

One of the main advantages of such international pledges is their ability to mobilize political wills behind the cause of incorporation of sustainability into institutes of higher education (Calder and Clugston, 2003). Such agreements encourage all universities to engage in education, research, policy formation, information exchange and community engagement on different trends of sustainability. At the same time, being a part of these international agreements brings about commitment to fulfill the criteria each university is committed to implement. Such agreements 
also provide a monitoring system for the improvement of incorporation of sustainability into member institutes.

Guiding Documents and Reports

Another important aspect of leadership is to have a clear practical vision and mission. Setting up a clear mission and vision can assist any institution on its route towards achieving its strategic goals and objectives (Taiwo et al., 2016). Addressing sustainability and its related issues in the vision and mission statements of the institutions of higher education can provide those institutions with a better understanding and action guideline towards sustainability.

For example, the mission statement of the Universiti Sains Malaysia (USM) can be considered as an example of how universities and colleges can infuse the holistic nature of sustainability in their mission statements. This mission statement declares, 'USM is a pioneering, trans-disciplinary research-intensive university that empowers future talents and enables the bottom billions to transform their socio-economic well-being.' Based on the proposed vision and mission, a series of initiatives were established at USM including, campaigns against Styrofoam and plastic on campus, establishment of RCE Penang, establishment of the Centre for Global Sustainability Studies, and sustainability scenario making (Koshy and Ibrahim, 2012). In recognition of its sustainability related efforts, USM was granted the Accelerated Programme for Excellence (APEX) title in 2008 by Ministry of Higher Education Malaysia to transform higher education for a sustainable tomorrow.

Another example of incorporation of sustainability agenda in the vision and mission of a university can be seen in Appalachian State University (AppState). In its mission statement, the university emphasize its role to lead in creating a world where environmental, societal, and economic qualities exist in balance to meet the resource needs of today and of future generations (Appalachian, 2020). AppState has been one of the most active universities in north America in committing itself to a wide range of sustainability initiatives including New Climate Action Planning writing begins (2019), Second Nature Climate Commitment (2016), and We Are Still In pledge (2018). One of the major efforts by AppState to follow its sustainability vision was to develop its Strategic Energy and Water Management Plan which commits it to reduce facility GHG by $11.5 \%$ and to decrease the energy and water use intensity by $19.9 \%$ and $2.5 \%$ before 2050.

The vision and mission statements create a center point for each institute to synchronize its members and their efforts around a central theme. This will ensure that all members are aware of the ultimate objectives of the organization and strategize their activities towards them. This will eventually elevate the efficiency and productivity of the organization as whole. The cases of USM and AppState clearly demonstrate the success of both institutes in achieving their strategic objectives through a clear sustainability-oriented vision and mission.

\section{Campus Community}

Implementing sustainability at a university with its complex working structure is not an easy task and cannot be done on personal accounts. In order to implement the goals and objectives which have been described in the vision and mission statement of the university, formation of some relevant teams and groups seems essential to identify the issues which needs to be attended and 
then to design an action plan/roadmap to address those issues accordingly. These groups can be created under different names such as; committee, taskforce, etc. in relation to the nature of issues they are assigned to address.

\section{Personnel Selection}

One of the most important matters in administrating a complex organization successfully is to choose the people who are synchronized or willing to be so with the vision and mission of that organization (Afshari et al., 2010). Universities cannot be exceptions in this process. The course of personnel selection should not be limited to the traditional or conventional aspects of it but to be expanded to the personnel training and development as well. This by time could ensure the well-functioning of them within the university setting and its vision. The selection of applicants for vacant positions shall be based upon a relative consideration of their qualifications, education, skills and experiences for the position to be filled.

For universities with sustainable development in their core agenda, it is important to facilitate the selection process for people with sustainability related experiences. However, in term of sustainability related mission, it is also vital to notice that having experience in sustainability related fields should not be covering the lack of required academic essentials. Apart from that, the selection should consider the applicants ready to adopt the values and policies of the employing faculty or center (Stone, 1991). Some of these values are common among all jobs such as willing to integrate with people from various backgrounds, willing to accept new ideas and respecting the environment. If we equip the people who have successfully passed the selection process with sustainability-oriented knowledge and skills, it can be a hoped to facilitate the process of change towards sustainability at that particular university.

One of the most important factors in implementing sustainability at institutes of higher education is their pluralism. It has to be ensured that the selection of staffs and students are well reflecting the diversity of the society in terms of; race, religion, gender, age, sexual orientation and physical abilities (Aramburu-Zabala, 2001). Exposing to people with different ideas and backgrounds can encourage the process of critical thinking among the employees.

\section{Orientation Programs}

After the selection process, the selected candidates should be exposed to series of trainings to develop their capacities on sustainability related issues. This can be achieved through different training and workshop series. Like any organizations, universities also conduct orientation programs for their new students and staff. These programs can introduce the newcomers to the sustainability-oriented vision and mission of the university.

Sustainability orientation activities at Harvard University can be considered as one the successful examples of such initiatives. These activities cover most of undergraduate and postgraduate students across all faculties through Harvard. Each year, over 3,000 reusable mugs and water bottles and more than 2,000 energy-efficient LED bulbs are distributed among the new students. Fresh students will be also introduced to recourse efficiency principles while checking in to their students residential on campus (Harvard University, 2020). The aim of such programs is to familiarize students with the basic concepts of sustainability and prepare them for adopting a more sustainable lifestyle while at Harvard. 
In another example, Universiti Sains Malaysia (USM) has started incorporating sustainability related education in its orientation programs for new students. The new USM students are being introduced to different trends of sustainability on campus during their orientation week. These trainings include subjects such as; methods to save energy, sustainable water consumption, recycling, composting, civic codes, healthy food consumption, environmental concerns, etc. The most important factor in these orientation programs is to engage the participants as much as possible. The participants should be involved in every stage of the program from planning to presenting their ideas.

In-service Learning

In-service learning is among the key mechanisms to elevate the knowledge and skills of employees in order to better achieve the organizational objectives (Kabadayi, 2016). In-service education and learning can therefore play a significant role in integrating sustainability among the university structure especially for the staffs. This would provide the unique opportunity for those staffs who have not gone through proper sustainability related orientation programs upon their employment at the university. This type of education seeks to extend people's concern and involvement beyond their individual self that is how we see our relationship and how we interact with the rest of the world. These programs would also encourage critical thinking among the staffs which is imperative when dealing with sustainability issues because the field is rife with taken-for-granted assumptions and practices that have long gone unquestioned.

An example of such in-service trainings can be seen in the case of Universite de Sherbrooke, Québec, Canada in which a bachelor's degree in Environmental Studies, supplemented by inservice training has been successfully implemented (Anand et al., 2016). The in-service learning component in this program is conducted by the University Centre for Environmental and Sustainable Development Studies (CUFE) and offers different short programs related to the environment and sustainability. These short programs are geared to engage the campus community especially the university's employees towards achieving the university's sustainability objectives (Leal-Filho et al., 2015).

While getting people to be critical and criticize regarding unsustainable lifestyles and practices is important, they should be guided and encouraged to go beyond criticizing and making a constructive contribution. In other words, people should be led to be more future-focused to examine, plan and realise probable and possible futures. It is therefore essential to maintain a long-term perspective for these in-service learning programs.

\section{Incentives}

Another important issues that needs to be considered in terms of developing human capital for sustainability at institutions of higher education is to motivate the academic and non-academic staffs to work and cooperate in the path of sustainability (Barth and Rieckmann, 2012). In many universities or colleges, the issue of sustainability or its related activities is an extra component to the traditional university functions. The sustainability related activities such as the environmental activities (recycling, tree planting, etc.) or the community engagement (conducting courses or executive projects in communities) are mostly voluntarily based. 
Therefore, there is need to consider the techniques to encourage and motivate the university staff to involve in such activities and to sustain their participation.

Allocation of some budget as incentives to cover these kinds of activities can positively elevate the level of encouragement and participation of the university staff in such activities. On the other hand, the university leadership should be able of conveying the message that they are serious about the sustainability activities (Wals and Jickling, 2002). This seriousness can be shown in different ways and by different mechanisms. An environment has to be created in which the university staff feel recognized by the authorities on what they do for sustainability related activities.

These mechanisms can vary from the immediate ones such as the pay raise and bonuses to the long-term ones such as increasing the KPI (Key Performance Indicators) and KIP (Key Intangible Performance). For implementing a successful long-term staff motivating system, some other administrative and governance sectors of the university should run through a 'sustainability reform' such as the university internal auditing section and its regulations and standards (Rees, 1995).

However, as Blackburn (2007) argues, among the most powerful motivators is a simple one: caring. Most employees will go to great lengths to help the organization and to satisfy the manager who they believe truly cares about their well-being. Emotional benefits can be more powerful than financial ones. Students on the other hand play also an important role in pursuing the cause of sustainability at any university. One of the most effective ways can be offering some academic credits to those students involved in voluntary sustainability related activities this can motivate many students in taking part in such project. However, the financial motivating techniques should not be ignored. On the other hand, students can be motivated by recognitions in term of certificates or letters of appreciations from the top authorities of the university.

\section{Monitoring and Evaluation}

Monitoring and evaluation (M\&E) are an integral part of any project cycle management including administrating institutes of higher education (Adams et al., 2018). M\&E must be a continuous process, right from the start to the very end, to show how well a system is meeting its targets and the overall goals. Good monitoring alerts decision makers at institutes of higher education about the emerging problems and provide valuable feedback to different stakeholders at institutes of higher education. In terms of human capital, the monitoring and evaluation system should measure the staff performance with regards to the overall sustainability objectives of the institution.

The monitoring tool which needs to be used in evaluating the staff performance is fully dependent on the purpose of the auditing. For this matter the objectives and scope of the monitoring should be well defined before the auditing take place. There are elements such as financial limitations in auditing which decide how deep or detailed the auditing can be. The expertise of those who want to conduct the auditing should be highly considered as well, on the other hand, there has to be a rough expectation on how cooperative the audited entity will be with the auditors. Since the auditing process requires a massive date collection, therefore, this bilateral cooperation seems to be vital. 
Sustainability Indicators

There are different types of Indicators for different periods in the lifetime of a project. Three such important periods and their associated indicators are 1) short-term - baseline, process, drivers, indicators, 2) mid-term - response, action, result indicators and, 3) long-term - outcome or impact indicators (Koshy et al., 2013). Indicators of sustainability are different from traditional indicators of economic, social and environmental changes. While traditional indicators measure changes in one part of the pillar areas of sustainability, as if it is entirely independent of other parts, sustainability indicators require an integrated view of the changes. For example, the wellpublicized indicator that measures the amount of money being spent in a country, the Gross Domestic Product (GDP), measures only the amount of economic activity whereas the Index of Sustainable Economic Welfare (ISEW) makes adjustments to GDP to reflect the harmful effects of economic activities on environment and society.

The sustainability indicators developed by Universiti Sains Malaysia (USM) is an interesting example in this case. These sustainability indicators were designed to measure and address the priorities highlighted in the USM Sustainability Roadmap. The Indicator Framework was designed to show the 'headline indicators' that go with the main goals for Water, Energy, Health, Agriculture, Biodiversity (WEHAB) and its cross sectoral areas described in the USM Sustainability Roadmap. In addition to the framework, Indicator Worksheets were also developed to show supplementary indicators as they relate to the various activities to be undertaken at USM (Koshy, et al., 2013).

The indicators may be direct or indirect depending on the objectives being measured. In developing sustainability indicators, the biggest problem is that the best indicators are those for which data is not usually available and where there is data, these are the least able to measure sustainability. Depending on the data availability, direct, proxy or interim indicators may be used taking care not to compromise the quality of the results. The primary objective of a well-planned and tested set of indicators is to rate the overall sustainability performance of the university with special focus on human capital.

\section{Conclusion}

This paper discussed the necessary ingredients for developing a committed human capital for sustainability in institutes of higher education. It is vital to realize that although incorporating sustainability into an institute of higher education should be through an organic bottom-up process, the role of a committed leadership cannot be ignored. As for institutes of higher education, the journey toward developing dedicated human capital starts from the commitment of the leadership to the principles of sustainable development. For leadership to commit itself to sustainability, several mechanisms were discussed in this paper. There are currently several international pledges and declarations for institute of higher education around the world to commit themselves to the idea of sustainable development. The first step for a college or university is to choose the right international pledges and declarations according to its capacities and join them. Being affiliated to international pledges paves the way for the leadership to implement the necessary initiatives. Based on the nature of the declaration an institute affiliates itself too, relevant guidelines and roadmaps can be designed and implemented to develop the human capital needed to run a university based on sustainability principles. 
To develop the human capital for sustainability in higher education, several measures should be taken into consideration at the implementation level. Selecting the right personnel plays a key role in this process. The personnel should be selected inline with the sustainability vision and mission of the institute. To achieve this objective, the institute of higher education should conduct consistent orientation programs and in-service training. These initiatives will assist the university employees to have a clearer and more professional understanding of the university's agenda for sustainability. Increasing the understanding of the staffs and students about sustainability will eventually assist the implementation of sustainability to face less resistance and hurdles. To increase the success rate of developing human capital for sustainability in higher education, a proper mechanism of incentives should be also put in place. The ultimate objective of this system should be to increase the university staffs and students' participation in the process of implementing sustainability throughout the institute.

Meanwhile to assess the success and failure of the system in developing the necessary human capital in higher education, a system of monitoring and evaluation should be established. The main objective of this system should be to demonstrate how well the system is meeting its targets and the overall goals. To do so, a set of relevant indicators are necessary to be developed. These indicators will provide the platform to quantify the progress of the system in terms of human capital performance for sustainability in higher education.

While this paper presents a conceptual framework needed for developing human capital in higher education, there is a need for further research to identify the best practices among institutes of higher education around the world. These best practices coupled with the conceptual framework offered in this paper can be pave the way for different colleges and universities around the world to develop and implement their own strategies for developing human capital for sustainability in higher education.

\section{References}

Adams, R., Martin, S., \& Boom, K. (2018). University culture and sustainability: Designing and implementing an enabling framework. Journal of Cleaner Production, 171, 434-445.

Adomssent, M., Godemann, J., Michelsen, G., Barth, M., Rieckmann, M., \& Stoltenberg, U. (2007). Developing key competencies for sustainable development in higher education. International Journal of Sustainability in Higher Education.

Afshari, A., Mojahed, M., \& Yusuff, R. M. (2010). Simple additive weighting approach to personnel selection problem. International Journal of Innovation, Management and Technology, 1(5), 511.

Altbach, P. G. (1993). The Dilemma of Change in Indian Higher Education. Higher Education, 26(1), 3-20.

Anand, C. K., Bisaillon, V., Webster, A., \& Amor, B. (2015). Integration of sustainable development in higher education-a regional initiative in Quebec (Canada). Journal of Cleaner Production, 108, 916-923.

Appalachian State University (2020). University Sustainability Mission, Vision \& Values. Available at: https://sustain.appstate.edu/mission/

Aramburu-Zabala, H. L. (2001). Adverse impact in personnel selection: The legal framework and test bias. European Psychologist, 6(2), 103. 
INTERNATIONAL JOURNAL OF ACADEMIC RESEARCH IN PROGRESSIVE EDUCATION AND

DEVELOPMENT

Vol. 9, No. 2, 2020, E-ISSN: 2226-6348 @ 2020 HRMARS

Barth, M., \& Rieckmann, M. (2012). Academic staff development as a catalyst for curriculum change towards education for sustainable development: an output perspective. Journal of Cleaner Production, 26, 28-36.

Blackburn, W. R. (2007). The Sustainability Handbook. Environmental Law Institute, TJ International Ltd. UK.

Blanco-Portela, N., Benayas, J., Pertierra, L. R., \& Lozano, R. (2017). Towards the integration of sustainability in higher education institutions: a review of drivers of and barriers to organisational change and their comparison against those found of companies. Journal of Cleaner Production, 166, 563-578.

Borys, T. (2010). Decade of education for sustainable development-Polish challenges. Problems of Sustainable Development, 5(1), 59-70.

Brown, J. R. (2000). Privatizing the University--The New Tragedy of The Commons. Science, 290 (5497), 1701-1702.

Burke, P. J. (2013). The Right to Higher Education: Beyond Widening Participation. Routledge.

Calder, W., \& Clugston, R. M. (2003). International efforts to promote higher education for sustainable development. Planning for higher education, 31(3), 30-44.

Carlson, S., (2006, October). In search of the sustainable campus. The Chronical of Higher Education, 53(9), 10-14.

Čiegis, R., \& Gineitienè, D. (2006). The Role of Universities in Promoting Sustainability. Engineering Economics, 48(3), 63-72.

Cortese, A. D. (1999). Education for Sustainability: The Need for a New Human Perspective. Second Nature.

Cortese, A. D., and McDonough, W. (2001). Accelerating the Transition to Sustainability Through Higher Education. Environmental Grantmakers Association News \& Updates, pp. 11-13, 34.

Darwish, S. (2014). Education and Human Capital Development in Bahrain:" Future International Collaboration with Malaysia. International Journal of Academic Research in Management (IJARM), 3(4), 321-334.

Darwish, S. (2014). Education and Human Capital Development in Bahrain:" Future International Collaboration with Malaysia. International Journal of Academic Research in Management (IJARM), 3(4), 321-334.

Etzkowitz, H., Webster, A., Gebhardt, C., \& Terra, B. R. C. (2000). The future of the university and the university of the future: evolution of ivory tower to entrepreneurial paradigm. Research Policy, 29(2), 313-330.

Frazzoli, C., Petrini, C., \& Mantovani, A. (2009). Sustainable development and next generation's health: a long-term perspective about the consequences of today's activities for food safety. Annali Dell'Istituto Superiore di Sanita, 45(1), 65-75.

Guri-Rosenblit, S. (1996). Trends in access to Israeli higher education 1981-96: From a privilege to a right. European Journal of Education, 31(3), 321-340.

Harvard University. (2020). Orientations Go Green. Available at: https://green.harvard.edu/news/orientations-go-green 
INTERNATIONAL JOURNAL OF ACADEMIC RESEARCH IN PROGRESSIVE EDUCATION AND

DEVELOPMENT

Vol. 9, No. 2, 2020, E-ISSN: 2226-6348 @ 2020 HRMARS

Kabadayi, A. (2016). A suggested in-service training model based on Turkish preschool teachersí conceptions for sustainable development. Journal of Teacher Education for Sustainability, 18(1), 5-15.

Koshy, K. C., and Ibrahim, K. (2012). Universiti Sains Malaysia's Sustainability Journey: Reflections on a Road Less Travelled. Centre for Global Sustainability Studies. Universiti Sains Malaysia.

Koshy, K. C., Nor, N. M., Sibly, S., Rahim, A. A., Jegatesen, G., \& Muhamad, M. (2013). An indicatorbased approach to sustainability monitoring and mainstreaming at Universiti Sains Malaysia. In Sustainability assessment tools in higher education institutions (pp. 237-258). Springer, Cham.

Krizek, K. J., Newport, D., White, J., \& Townsend, A. R. (2012). Higher education's sustainability imperative: how to practically respond? International Journal of Sustainability in Higher Education.

Leal Filho, W., Azeiteiro, U., Caeiro, S., \& Alves, F. (2015). Integrating sustainability thinking in science and engineering curricula. Zurich: Springer.

Painter-Morland, M., Sabet, E., Molthan-Hill, P., Goworek, H., \& de Leeuw, S. (2016). Beyond the curriculum: Integrating sustainability into business schools. Journal of Business Ethics, 139(4), 737-754.

Rees, W. E. (1995). Achieving sustainability: reform or transformation? Journal of planning literature, 9(4), 343-361.

Shriberg, M., \& MacDonald, L. (2013). Sustainability leadership programs: Emerging goals, methods \& best practices. Journal of Sustainability Education, 5(1).

Sitarz, D. (1993). Agenda 21: The earth summit strategy to save our planet.

Spillane, J. P., Halverson, R., \& Diamond, J. B. (2001). Investigating school leadership practice: A distributed perspective. Educational researcher, 30(3), 23-28.

Sterling, S. (2004). Higher education, sustainability, and the role of systemic learning. In Higher Education and the Challenge of Sustainability (pp. 49-70). Springer, Dordrecht.

Stone, R. J. (1991). Expatriate selection and failure. Human Resource Planning, 14(1).

Taiwo, A. A., Lawal, F. A., \& Agwu, E. (2016). Vision and Mission in Organization: Myth or Heuristic Device? The International Journal of Business \& Management, 4(3).

Tappeiner, G., Tappeiner, U., \& Walde, J. (2007). Integrating disciplinary research into an interdisciplinary framework: A case study in sustainability research. Environmental Modeling \& Assessment, 12(4), 253-256.

UN World Commission on Environment and Development, (1987), 42nd session, Agenda item 82e, Resolutions adopted by the General Assembly, United Nations, New York, USA.

UNESCO. (2009). Bonn Declaration, UNESCO World Conference on Education for Sustainable Development, 31 March-2 April 2009.

van Dam-Mieras, M. C. E., \& Rikers, J. H. A. N. (2007). RCE Rhine-Meuse: towards learning for sustainable development. Journal of Education for Sustainable Development, 1(1), 51-60.

Wals, A. E., \& Jickling, B. (2002). "Sustainability" in higher education. International Journal of Sustainability in Higher Education. 